\title{
ПАМ'ЯТІ ІГОРЯ ПОРФИРІЙОВИЧА ШЛАПАКА
}

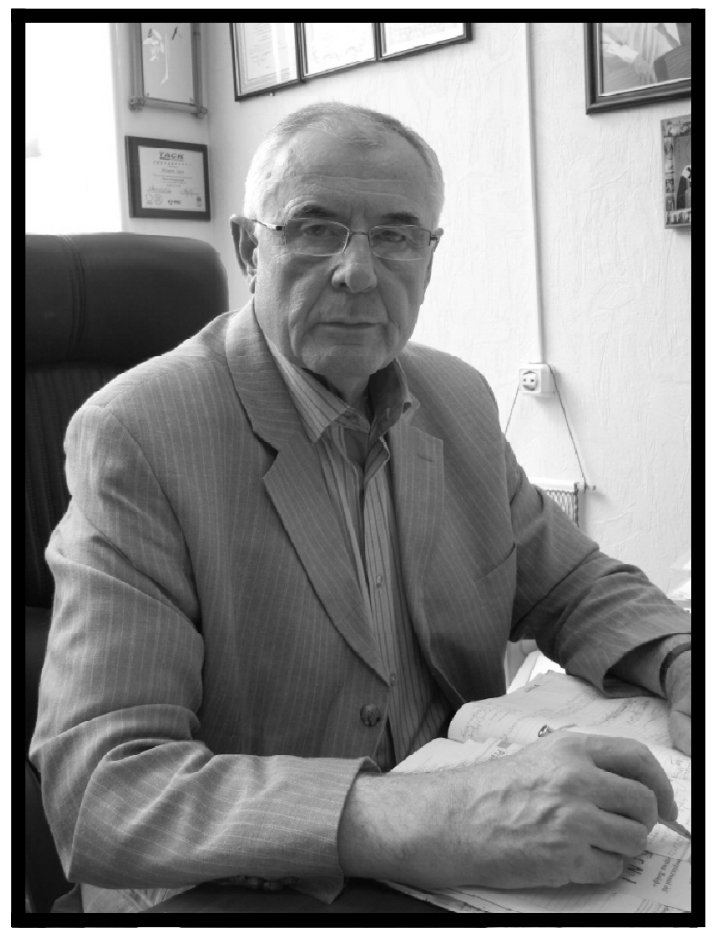

Кафедра анестезіології та інтенсивної терапії НМАПО імені П.Л.Шупика з глибоким сумом сповіщає про те, що 20 вересня 2015 року на 72 році життя раптово помер відомий вітчизняний анестезіолог, завідувач кафедри анестезіології та інтенсивної терапії Національної медичної академії післядипломної освіти імені П.Л.Шупика, професор Ігор Порфирійович Шлапак.

І.П.Шлапак народився 29 вересня 1943 року в сім'ї педагогів на Вінничині. В 1968 році закінчив з відзнакою Київський медичний інститут імені О.О.Богомольця. Свою трудову діяльність в анестезіології та реаніматології І.П.Шлапак почав в одному 3 провідних лікувальних закладів Києва - клінічній лікарні імені Жовтневої революції (нині - Олександрівська лікарня м.Києва). В 1970 році І.П.Шлапак вступив до аспірантури на кафедру анестезіології і реаніматології Київського державного інституту удосконалення лікарів, міцно зв'язавши своє життя з цим науковим і навчальним закладом. В 1975 році він захистив кандидатську дисертацію, присвячену екстракорпоральній перфузії ізольованої печінки.

З 1974 по 1987 роки працював асистентом, а з 1987 року - доцентом кафедри анестезіології і реаніматології Київського державного інституту удосконалення лікарів.

В рамках становлення в Україні медицини критичних станів в Києві створюється науково-практичне об'єднання швидкої медичної допомоги та медицини катастроф. В 1994 році в цій установі клініку анестезіології, інтенсивної терапії та реанімації очолив І.П.Шлапак. 3 цього часу і до 2005 року він був беззмінним головним спеціалістом МОЗ України в галузі клінічної токсикології, і розвиток токсикологічної служби в нашій країні нерозривно пов'язаний з іменем І.П.Шлапака. 
В 1995 році І.П.Шлапак захистив докторську дисертацію, а в 1996 році очолив кафредру анестезіології та інтенсивної терапії Національної медичної академії післядипломної освіти імені П.Л. Шупика. У 1998 року кафедра під керівництвом І.П.Шлапака стає опорною серед подібних кафедр України. 3 того часу протягом багатьох років кафедра анестезіології та інтенсивної терапії НМАПО імені П.Л.Шупика утримує передові позиції в організації навчального процесу, методичній, науковій та лікувальній роботі. І в цьому велика заслуга її керівника - професора І.П.Шлапака.

Наукові інтереси І.П.Шлапака були надзвичайно широкими і стосувалися проблем інтенсивної терапії черепно-мозкової та поєднаної травм, гострих отруєнь та інсультів, сепсису, шоку, цукрового діабету, гострого панкреатиту, лікування больових синдромів, застосування регіонарної анестезії тощо.

Ігор Порфирійович Шлапак був автором понад 350 наукових публікацій з різних проблем анестезіології та інтенсивної терапії. Серед них - перший національний підручник "Анестезіологія та інтенсивна терапія" під редакцією І.П.Шлапака, 17 наукових посібників і монографій. Він був членом редакційних рад і редколегій 7 наукових медичних часописів, беззмінним головним організатором і співголовою оргкомітету міжнародних форумів "Британо-український симпозіум з анестезіології та інтенсивної терапії", що стали відомими і популярними не тільки в Україні, але й далеко за її межами.

Професор І.П.Шлапак плідно розвивав вітчизняну анестезіологію та інтенсивну терапію з багатьма своїми колегами та учнями. Він особисто підготував 26 кандидата та 5 докторів медичних наук.

Ігор Порфирійович Шлапак - заслужений діяч науки і техніки України (2003), академік Академії наук вищої освіти (2010), віце-президент Асоціації анестезіологів України, Голова Спеціалізованої вченої ради Д.26.613.02 по захисту докторських і кандидатських дисертацій при Національній академії післядипломної освіти імені П.Л.Шупика, член проблемної комісії з анестезіології та інтенсивної терапії МОЗ та АМН України.

Колеги, співробітники та учні з глибокою скорботою висловлюють співчуття родичам та близьким. Вічна пам'ять про видатного науковця, Вчителя та Колеги назавжди залишиться в наших серцях.

Асоціація анестезіологів України Редакція журналу "Біль, знеболювання і інтенсивна терапія" Співробітники кафедри анестезіології та інтенсивної терапії НМАПО імені П.Л.Шупика 